\title{
Evaluation of Quality of Life in Women with HIVIAIDS According to the HAT-QoL
}

\author{
Francisco Dimitre Rodrigo Pereira Santos', Leila Rute Oliveira Gurgel do Amaral², \\ Simony Fabíola Lopes Nunes ${ }^{3}$, Claudia Regina de Andrade Arrais Rosa ${ }^{4}$, \\ Edem Oliveira Milhomem Filho ${ }^{5}$, Viviany Assunção Lima ${ }^{6}$, Laiana Neponuceno dos Santos ${ }^{7}$
}

\section{Abstract}

Objective: Check the socio-demographic profile and quality of life of women living with HIVIAIDS in the city of Imperatriz, MaranhãoBrazil and make a correlation between the domains of quality of life with the age, education, and individual income.

Method: This is a cross-sectional and quantitative study, conducted in the Specialized Care Service of patients with HIVIAIDS the city of Imperatriz, Maranhão-Brazil; which treats patients from southern Maranhão-Brazil, state of Pará-Brazil and Tocantins-Brazil. Socio-demographic data were collected through a structured questionnaire, containing data on age, marital status, education, occupation, individual income and sexually active; and to assess the quality of life used the instrument HIVIAIDS Targeted Quality of Life-HAT-QoL; what evaluates the quality of life in 9 dimensions; being these dimensions; general function, satisfaction with life, health concerns, financial concerns, concerns about the medication, acceptance of HIV, confidentiality concerns, trust in the professional, and sexual function. The scores range from 0 to 100 , where 0 is the worst possible score and 100 is the best possible score, and considered as mild damage the quality of life domains that had scores below 70 and the bad with scores below 50, influencing negatively the quality of life. Data were analyzed using the statistical program BioEstat 5.0 considering a $5 \%$ level of significance $(p \leq 0.05)$.

Results: Thirty-nine women participated in the study, 53.9\% were aged over 40 years old, single, had at most completed elementary school and retired; $61.5 \%$ had an individual income of one minimum wage, and all were sexually active. Regarding the quality of life, the domains with scores below 50 were financial concerns, acceptance
1 Physical Therapist, Master's Degree in Health Sciences, Federal University of Tocantins. Imperatriz, Maranhão, Brazil.

2 Psychologist, Ph.D. in Psychology, professor at the Federal University of Tocantins. Palmas, Tocantins, Brazil.

3 Nurse, Master's Degree in Nursing, professor at the Federal University of Maranhão. Imperatriz, Maranhão, Brazil.

4 Nurse, Ph.D in Biotechnology, professor at the Federal University of Maranhão. Imperatriz, Maranhão, Brazil.

5 Pharmacist, Master's Degree in Tropical Diseases, professor at the Federal University of Maranhão. Imperatriz, Maranhão, Brazil.

6 Nurse, Federal University of Maranhão. Imperatriz, Maranhão, Brazil.

7 Physical Therapist, Lutheran University Center Palmas. Palmas, Tocantins, Brazil.

Contact information:

Francisco Dimitre R. Pereira Santos.

झ franciscodimitre@hotmail.com 
of HIV and sexual function, domains overall function, life satisfaction, health concerns, presented a slight loss in the life of the woman who lives with AIDS, with scores greater than 50 and less than 70; since the concerns domains with the medication and confidence in the professional, showed scores above 70. The scores of HAT-QoL domains shown to be correlated with age, education and individual income of women living with AIDS, age was a statistically significant result with the concern confidentiality domain $(p=0.01)$, education, the only domain that showed significant relationship was trust in the professional $(p=0.04)$.

Conclusion: Even after thirty-six years of the emergence of AIDS, it is still a barrier for HIV-positive women accept their health condition and the concern to conceal the diagnosis. The sexual intercourse of women living with AIDS show a domain that negatively alters their quality of life, however trust in the health professional and the use of medications did not interfere in the lives of the interviewees. Women with higher age and with low levels of education and income are beginning to emerge in the scenario of those living with AIDS, showing a direct relationship with quality of life, especially regarding age and education.

\author{
Keywords \\ Quality of Life; Women's \\ Health; Acquired Immune \\ Deficiency Syndrome.
}

\section{Introduction}

For a long time, the epidemiological profile of AIDS remained stable, however, in the present days is observed a change in this profile, changes as internalization, epidemiological visibility, heterosexual and a large quantity of cases diagnosed in women, suggesting that AIDS is now no longer restricted to those who were considered risk groups (homosexuals, injecting drug users and sex workers) [1].

Women diagnosed with AIDS face many difficulties, from those related to health and disease status, going to the affection and the relationship because according to their sociocultural context, to take care of home and family is a responsibility of women. Most new cases of infection among females are due to monogamous relationships by women, and they discover treachery only after their husband's illness [2].
After thirty-six years of AIDS discovery, it is noticeable that it was marked by prejudice and discrimination, in this context, the woman with AIDS presents unique characteristics due to pathophysiological disease situation and the gender position that women occupy in the patriarchal society. AIDS is a threat to women; it is true that man and woman can be infected with HIV, and may or may not subsequently become ill; but once a woman is contaminated, they can pass to their baby during pregnancy, and the disease becomes a threat not only to her but also to the generated child. Another factor that we must consider is the responsibility of the woman because they are responsible for the home care of the sick [3].

At the moment of the positive diagnosis confirmation, fear is present, not only the fear of death (originated by AIDS) but also the fear of prejudice, 
fear of not receiving social support and fear that other people know about your health. For women, after receiving a positive diagnosis for HIV, they begin to re-evaluate their life, and life goals are idealized again [4].

Patients with AIDS have a higher longevity due to the medicine advances and due to the advances in drug therapies distributed in Brazil for free and universal form, as well as conducting periodic tests to monitor the health status of the patient; as a consequence of improving the quality of life of people living with AIDS; however not only the biomedical indicators influence but also the socio-demographic indicators.

Biopsychosocial factors, in the case of women with AIDS, can be listed in the impact on the emotional, social, cultural and sexual life. Sousa et al. [5] bring that some patients living with AIDS have negative changes in quality of life because of prejudice and relationship with death, both built at the beginning of the epidemic and present today in the population imagination. To assess the quality of life of women living with AIDS, the analysis of sociodemographic profile is essential, as the interactions and relationships built by the infected women influence beneficially or not. Thus, this study aimed to check the socio-demographic profile and quality of life of women living with HIVIAIDS in the city of Imperatriz-MA and make a correlation between the domains of quality of life with the age, education, and individual income.

\section{Methods}

This was a cross-sectional and quantitative study conducted in the Specialized Care Service of patients with HIVIAIDS (SCS) the city of Imperatriz, Maranhão-Brazil; which treats patients from southern Maranhão-Brazil, state of Pará-Brazil and TocantinsBrazil. Data were collected from January to June 2015, always on tuesdays and thursdays during the medical and nursing consultations. They included randomized women who were at the health unit; with AIDS diagnosis for over one year, confirmed in the handbook; who made use of antiretroviral drugs and aged over 18 years old, those with difficulty understanding the questions of the questionnaires, with weakened health and cognitive deficit were excluded.

According to data reported by the SCS, the number of women regularly registered, diagnosed as seropositive for HIV for over one year and making regular use of antiretroviral drugs, was 60 patients. Through an unproblematic sampling, the sample consisted of 52 women, and was initially defined which was the sampling error tolerable for the stu$d y$, using the following statistical calculation:

$$
n_{0}=\frac{1}{E_{0}^{2}}
$$

Where:

- $\mathbf{n}_{\mathbf{0}}$ : is the first approximation of the sample size

- $\mathbf{E}_{0}$ : is the tolerable sampling error $(5 \%=0.05)$ The following formula was used for setting the sample quantity

$$
n=\frac{N \cdot n_{0}}{N+n_{0}}
$$

Where:

- $\mathbf{N}$ : is the number of elements of the population (60)

- $\mathbf{n}$ : is the sample size

Two questionnaires were used for data collection; the first about the socio-demographic data and the second about HIVIAIDS-Quality of Life (HAT-QoL), which is a specific tool for assessing the quality of life of people living with HIVIAIDS. The HAT-QoL evaluates the quality of life in 9 dimensions; each dimension is divided into 2-6 issues, being these dimensions; general function, satisfaction with life, health concerns, financial concerns, concerns about the medication, acceptance of HIV, confidentiality concerns, trust in the professional, and sexual 
function. All dimensions are scored, and the final score of each dimension is transformed into a linear scale from 0 to 100, where 0 is the worst possible score and 100 is the best possible score, and considered as mild damage the quality of life domains that had scores below 70 and the bad with scores below 50, influencing negatively the quality of life.

Data were analyzed using the statistical program BioEstat 5.0. Demographic data were presented by frequency distributions and descriptive measures; and HAT-QoL data were presented through a descriptive analysis to verify the correlation between socio-demographic variables and domains of the HAT-QoL questionnaire of quality of life, the Spearman correlation test was used, when $r s=0$ shows that there is no correlation between the variables, and when $r s \neq 0$ shows that there is a correlation between the analyzed variables, it was considered a $5 \%$ level of significance $(p \leq 0.05)$. The study met the national and international principles of ethics in research involving human beings, and the study was approved by the Research Ethics Committee on Human Beings of the Federal University of Tocantins, UFT, with protocol number 105/2014.

\section{Results}

Of the 52 women, 13 were excluded because they did not felt comfortable to participate in the research, resulting 39 participants. The results will be exposed below in tables, divided into three categories, the first is the socio-demographic profile of the sample, the second the data related to the quality of life, and the third refers to the correlation between the domains of quality of life of women with AIDS with the age, education, and individual income.

\section{Socio-demographic characteristics of women living with AIDS}

Regarding the age, $53.9 \%$ of the sample consisted of women over 40 years old; verifying the marital status, a smaller portion of the sample (46.1\%) were married or in a consensual union, and most had no fixed partners, representing $53.9 \%$ of the sample, with these data it is possible to verify that most women living with AIDS have no marital relationships. The education of the sample was described in years of study and was evidenced that $59 \%$ of the sample completed only primary education, showing that a large proportion of women with AIDS had a low level of education. $53.9 \%$ were retired or received a pension while $25.6 \%$ had steady employment and $20.5 \%$ were unemployed and had no individual income, depending on the income of the family group, $61.5 \%$ had an individual income of one minimum wage and only $18 \%$ had individual income higher than one minimum wage (Table 1).

Even a large part of the sample does not show stable marital relationships, all had active sexual life (Table 1), and we can verify that AIDS was not a

Table 1. Socio-demographic and economic characteristics of women.

\begin{tabular}{|c|c|}
\hline Variables & n (\%) \\
\hline \multicolumn{2}{|l|}{ Age (years) } \\
\hline $20-40$ & $18(46.1)$ \\
\hline$\geq 40$ & $21(53.9)$ \\
\hline \multicolumn{2}{|l|}{ Marital Status } \\
\hline Married/Consensual Union & $18(46.1)$ \\
\hline Single/Widower & $21(53.9)$ \\
\hline \multicolumn{2}{|l|}{ Education (years) } \\
\hline$\leq a 8$ & $23(59)$ \\
\hline$\geq 10$ & $16(41)$ \\
\hline \multicolumn{2}{|l|}{ Occupation } \\
\hline Retired/Pensioner & 21(53.9) \\
\hline Employed & $10(25.6)$ \\
\hline Unemployed & $8(20.5)$ \\
\hline \multicolumn{2}{|l|}{ Individual Income* } \\
\hline Without income & $8(20.5)$ \\
\hline One minimum wage & $24(61.5)$ \\
\hline$\geq$ one minimum wage & $07(18)$ \\
\hline \multicolumn{2}{|l|}{ Sexually active } \\
\hline Married/Consensual Union & $18(46.1)$ \\
\hline Single/Widower & $21(53.9)$ \\
\hline
\end{tabular}


Table 2. Descriptive measures of the domains of the assessing scale of the quality of life by the HAT-QoL.

\begin{tabular}{|l|c|c|c|c|c|}
\hline \multicolumn{1}{|c|}{ Domains } & Average ( $\mathbf{( S D})$ & Maximum & Minimum & P25 & P75 \\
\hline General & $67(24.7)$ & 100 & 12,5 & 50 & 87.5 \\
\hline Life Satisfaction & $64(30.0)$ & 100 & 0 & 43.75 & 84.375 \\
\hline Health concerns & $61(31.8)$ & 100 & 0 & 31.25 & 87.5 \\
\hline Financial concerns & $44(37.7)$ & 100 & 0 & 0 & 70.83 \\
\hline Medication concerns & $73(24.7)$ & 100 & 15 & 55 & 100 \\
\hline Acceptance of HIV & $42(34.6)$ & 100 & 0 & 6.25 & 62.5 \\
\hline Confidentiality concerns & $41(33.7)$ & 100 & 0 & 10 & 61.25 \\
\hline Confidence in the professional & $85(26.1)$ & 100 & 0 & 83.33 & 100 \\
\hline Sexual function & $41(34.0)$ & 100 & 0 & 0 & 62.5 \\
\hline
\end{tabular}

SD: Standard Deviation; P25: percentile to 25; P75: percentile to 75.

limitation for sexual practice, however, sexual intercourse need to be safe and must use condoms, not infecting their partner if they are not HIV positive, and if the couple is positive, they should avoid possible co-infections; it makes sex to negatively interfere with women's quality of life living with AIDS (Table 2).

\section{Evaluation of quality of life of women with AIDS according to the HAT-QoL}

In the evaluation the quality of life by the HATQoL, of the nine domains, four had scores below 50. Currently, women became active in society and showed financially independence, but AIDS can be a limitation for them on employment search and income generation, in the financial worries domain (44), it appears that it badly interferes with the quality of life of women with AIDS. As can be observed, the acceptance of HIV (42) is still a great difficulty for the woman, a factor that may be related to stereotypes constructed at the beginning of the AIDS epidemic. It is possible to verify that the concern of others people about their condition and health is something that worries women changing their quality of life negatively, as can be seen in the domain, confidentiality concerns (41); regarding sexual function a score of 41 was identified, showing that sex practice negatively affects the lives of women with AIDS (Table 2).
The domains with mild impairment in the quality of life of women living with AIDS were three: the general function (67), satisfaction with life (64) and health concerns (61). Concern with the medication (73) and confidence in the professional (85) (Table 2) were the two domains that had higher scores among the nine domains of quality of life; adherence to medications are adjuncts to the maintenance of health; even aware of the side effects that medication can bring, did not show to be a concern of the interviewed women, a factor that may influence the approach that the professional performs in the study SCS because as can be seen in the program professionals, confidence was the domain with the highest score.

\section{Correlation between the domains of quality of life and socio-demographic data} The scores of the HAT-QoL domains shown to be correlated with age, education and individual income of women living with AIDS; however, when analyzing the individual income with the domains of quality of life, it was observed that there is no statistically significant correlation; but age was statistically significant with the confidentiality concern domain $(p=0.01)$, showing that patients with higher age show more concerned with hiding their HIV status; regarding education, the only domain that showed significant relationship was confidence in 
the professional ( $p=0.04)$, so it is possible to verify that women with low levels of education have more confidence in health professionals, as they provide health information to have a better quality of life and clarify their doubts about AIDS (Table 3).

Table 3. Correlation between the domains of quality of life and age, education, and individual income.

\begin{tabular}{|c|c|c|c|}
\hline \multirow{2}{*}{$\begin{array}{l}\text { HAT-QoL } \\
\text { Domain }\end{array}$} & Age & Education & $\begin{array}{l}\text { Individual } \\
\text { Income }\end{array}$ \\
\hline & rs (p) & rs (p) & rs (p) \\
\hline General function & $0.004(0.9)$ & $0.07(0.6)$ & $0.018(0.9)$ \\
\hline Life satisfaction & $-0.05(0.7)$ & $-0.04(0.7)$ & $-0.04(0.7)$ \\
\hline Health concerns & $0.11(0.4)$ & $-0.08(0.5)$ & $0.13(0.4)$ \\
\hline Financial concerns & $0.10(0.5)$ & $0.01(0.9)$ & $0.22(0.1)$ \\
\hline $\begin{array}{l}\text { Medication } \\
\text { concerns }\end{array}$ & $0.25(0.1)$ & $-0.24(0.1)$ & $0.12(0.4)$ \\
\hline Acceptance of HIV & $0.22(0.1)$ & $0.06(0.6)$ & $0.05(0.7)$ \\
\hline $\begin{array}{l}\text { Confidentiality } \\
\text { concerns }\end{array}$ & $0.39(0.01)^{\star}$ & $-0.16(0.3)$ & $0.08(0.5)$ \\
\hline $\begin{array}{l}\text { Confidence in the } \\
\text { professional }\end{array}$ & $-0.11(0.5)$ & $-0.31(0.04)^{*}$ & $-0.22(0.1)$ \\
\hline Sexual function & $-0.29(0.07)$ & $0.20(0.2)$ & $0.03(0.8)$ \\
\hline
\end{tabular}

rs: Spearman correlation. ${ }^{*} p<0.05$

\section{Discussion}

As in the present research, women belonging to the study of Galvão et al. [6] presented aged between 19 and 56 years old, where most were older than 40 years; regarding marital status, $60.3 \%$ of the sample were married or lived with a partner, showing that the majority of women living with AIDS had marital relations, this statement diverges with the data found in this research where 53.9\% of women had no partner, being single or widowed.

Still in Galvão et al. [6] research, in the total of the sample, $64.3 \%$ lived with income below one minimum wage, but in the present research most women lived with individual income of one minimum wage. Sasani et al [7] states that the pauperization is a concern in the disease, as it has an impact on their social, family, emotional and sexual relations- hips, and consequently negatively compromising the quality of life; this statement was also demonstrated in this study, where low-income influenced the sample quality of life of the study, being financial concerns an instrument of HAT-QoL domain that showed poor scores.

Okuno et al [8] found in his research that the majority of AIDS patients have only primary school, and about the occupation most were retired or pensioners, these two variables corroborate those found in this study.

All female members of this research were sexually active, with fixed or not partners, however the sexual function domain assessed by HAT-QoL showed a negative change in women's quality of life living with AIDS, as well as the study by Gaspar et al [9], where a negative change was identified in sexual function as a result of AIDS, mainly for fear of infecting their partner because women still have difficulty negotiating condom use.

In the present research, another domain which also showed a loss in the women's quality of life was the secrecy concern; in the study Galvão et al. [10] this was the domain with the lowest score among others, as well as in Okuno et al. [8] research. Meirelles et al. [11] and Okuno et al. [12] show that secrecy concern is the result of prejudice built about AIDS, for fear of being rejected by society, the woman worries to hide the diagnosis. Prejudice and secrecy concern negatively interfere in a woman's life living with AIDS, these factors most often interfere even in treatment adherence and completion of laboratory tests because the patient is afraid to attend health unit.

To accept their health condition women depends on the socio-cultural factors, in this study the acceptance of HIV domain proved to be a domain that interferes negatively on women's quality of life with AIDS, however in Galvão et al. [6] research, this domain had high scores, showing not being an aggravating domain in the lives of the interviewees. 
The domains general function, life satisfaction, and health concerns presented scores below 70 showing a slight injury to women's quality of life living with AIDS. The general function domain concerns limitations caused by the presence of AIDS related to physical activity, routine activities of everyday life, work and social activities in general. In the study by Soares et al. [13], among these three domains, the only one that presented a score with mild impairment in quality of life was health concerns; in the study Galvão et al. [6] this domain showed poor scores negatively affecting the woman's quality of life living with AIDS, diverging with the data found here; in the study of both authors cited above, general function and life satisfaction domains showed scores up to 70 , in contrast with the scores found in this investigation. Carvalho \& Galvão [4] show that after the woman receiving a positive diagnosis for HIV, concerns arise about how their new life will be; however receiving information from the health team, these health concerns become softened improving their quality of life.

When the patients trust in health care professionals, a healthy doctor-patient relationship is demonstrated, and this confidence positively interfere in the quality of life o the patient [11]. According to Costa et al. [14], the relationship that is established between health professionals and patients with AIDS is greatly important to the adhesion treatment process, becoming a therapeutic tool, through a good interrelation, empathy, communication and information transmission to the patient. The domain confidence in the health professional was the domain with the highest score found, showing that patients attended in the health unit put their confidence in the professionals that accompany them, and this is not a concern for them; as in the study of Sousa et al. [5] that among the nine domains this had the highest score; and in Galvão et al. [10] research, low scores in the professional confidence domain were identified.
Another domain with a high score was the medicines concerns, in the study Galvão et al. [10] and Real et al. [15] medication concern showed a great loss to the quality of life, being different from the data found in this study and the Okuno et al. [8] research.

The results of Okuno et al. [8] research, shows that the HAT-QoL domains, show correlation with age and individual income, however, did not show significant results in any of the nine domains; but in this study age was directly related to concern about confidentiality, another research had a relationship between low income and commitment in general health state [16], different from the results found in this research and Okuno et al. [8] research; Soares et al. [13] found that the income is correlated with the general function and financial concern.

By correlating the education to the nine quality domains, only confidentiality in the professional showed a statistically significant relationship, as in Soares et al [13] the research domain that showed a significant correlation was the financial concern.

\section{Conclusion}

Women with higher age and with low levels of education and income are beginning to emerge on the scene of those living with AIDS, being these variables a fact of public health concern as they may have a direct relationship with the quality of life, particularly as refers to age and education.

Concerning the positive aspects of women's quality of life living with AIDS, it was possible with this research to highlight confidentiality in the professional and medication concerns, indicating that the professional support can encourage treatment adherence; but the acceptance of HIV, secrecy concern and sexual functions shown to be domains that negatively interfere the lives of HIV-positive woman.

Through this research, it was possible to verify that age has a direct correlation with the secrecy concern and education with confidentiality in the 
professional. We suggest conducting further research with larger samples and relating other sociodemographic variables with the quality of life of women living with AIDS.

This research has limitations in terms of sample size, deserving further studies on the thematic with a larger sample, though not downgrading the study in question was not possible to make a discussion with local studies explaining the AIDS context in the region they are restricted to scientific research on the issue of AIDS in the city and region.

\section{References}

1. Brasil - Ministério da Saúde-Programa Nacional de DST/Aids. A epidemia da aids através do tempo [Internet]. Available from: http://www.ioc.fiocruz.br/aids20anos/linhadotempo.html.

2. Abdalla FTM, Nichiata LYI. A Abertura da privacidade e o sigilo das informações sobre o HIV/Aids das mulheres atendidas pelo Programa Saúde da Família no município de São Paulo, Brasil. Saúde Soc. [Internet], São Paulo, 2008 Apr/Jun; 17(2): 14052. Available from: http://www.scielo.br/scielo.php?script=sci arttext\&pid=S0104-12902008000200014\&Ing=en. http://dx.doi.org/10.1590/S0104-12902008000200014.

3. Reis AL, Xavier IM. Mulher e AIDS: rompendo o silêncio de adesão. Rev Bras Enferm. [Internet], Brasilia, 2003 Jan/Feb; 56(1): 2834. Available from: http://www.scielo.br/scielo.php?script=sci arttext\&pid=S0034-71672003000100006\&lng=en. http://dx.doi.org/10.1590/S0034-71672003000100006.

4. Carvalho CML, Galvão MTG. Enfrentamento da AIDS entre mulheres infectadas em Fortaleza - CE. Rev Esc Enferm. USP [Internet], São Paulo, 2008 Mar; 42(1): 90-7. Available from: http://www.scielo.br/scielo.php?script=sci arttext\&pid=S008062342008000100012\&lng=en. $\quad$ http://dx.doi.org/10.1590/ S0080-62342008000100012.

5. Silva ACO, Leadebal ODYCP, Freitas FFQ, Holmes ES, Albuquerque SGE, et al. Quality of life evaluation of elderly people living with HIVIAIDS according to HAT-QoL. Inte Archives Medicine [Internet], 2016, 9(37): 1-10. Available from: http:// imed.pub/ojs/index.php/iam/article/view/1499. http://dx.doi. org/ 10.3823/1908

6. Galvão, MTG, Cerqueira, ATAR, Machado, JM. Avaliação da qualidade de vida de mulheres com HIVIAIDS através do HAT-QoL. Cad Saúde Pública [Internet], Rio de Janeiro, 2004 Mar/Apr; 20(2): 430-37. Available from: http:// www.scielo.br/scielo.php?script=sci arttext\&pid=S0102311X2004000200010\&lng=en. $\quad$ http://dx.doi.org/10.1590/ $\underline{\text { S0102-311X2004000200010. }}$
7. Sasani L, Naji SA, Abedi HA. Psychic and psychological experiences of AIDS patients: A phenomenological study. Jundi Jour Chronic Disease Care [Internet], 2015 Jul; 2(3), 9-17. Available from: http://www.sid.ir/en/VEWSSID/J pdf/5060720130307. pdf.

8. Okuno MFP, Gomes AC, Meazzini L, Scherrer JG, Belasco JD, Belasco AGS. Qualidade de vida de pacientes idosos vivendo com HIV/AIDS. Cad Saúde Pública [Internet], Rio de Janeiro. 2014 Jul; 30(7):1551-9. Available from: http:// www.scielo.br/scielo.php? script=sci arttext\&pid=S0102311X2014000701551\&lng=en. http://dx.doi.org/10.1590/0102311X00095613.

9. Gaspar J, Reis RK, Pereira FMV, Neves LAS, Castrighini CC, Gir E. Qualidade de vida de mulheres vivendo com o HIV/aids de um município do interior paulista. Rev Esc Enferm. USP [Internet], São Paulo, 2011 Mar; 45(1): 230-6. Available from: http://www.scielo.br/scielo.php?script=sci arttext\&pid=S008062342011000100032\&lng=en. $\quad$ http://dx.doi.org/10.1590/ $\underline{\text { s0080-62342011000100032. }}$

10. Galvão MTG, Soares LL, Pedrosa SC, Fiuza MLT, Lemos LA. Qualidade de vida e adesão à medicação antirretroviral em pessoas com HIV. Acta Paul Enferm. [Internet], São Paulo, 2015 Feb; 28(1): 48-53. Available from: http:// www.scielo.br/scielo.php?script=sci arttext\&pid=S010321002015000100048\&lng=en. http://dx.doi.org/10.1590/19820194201500009.

12. Okuno MFP, Gosuen GC, Campanharo CRV, Fram DS, Batista REA, Belasco AGS. Quality of life, socioeconomic profile, knowledge and attitude toward sexuality from the perspectives of individuals living with Human Immunodeficiency Virus. Rev Latino-Am. Enfermagem [Internet], Ribeirão Preto, 2015 Mar/Apr; 23(2): 192-9. Available from: http:// www.scielo.br/scielo.php?script=sci arttext\&pid=S0104$\underline{11692015000200003 \& \text { lng }=e n}$. http://dx.doi.org/10.1590/01041169.3424.2542.

13. Soares GB, Garbin CAS, Rovida TAS, Garbin AJI. Quality of life of people living with HIVIAIDS treated by the specialized service in Vitória-ES, Brazil. Ciênc Saúde Coletiva [Internet], Rio de Janeiro, 2015 Apr; 20(4): 1075-84. Available from: http:// www.scielo.br/scielo.php?script=sci arttext\&pid $=$ S141381232015000401075\&lng=en. http://dx.doi.org/10.1590/1413$\underline{81232015204.00522014}$ 
14. Costa FM, Souza IC, Ribeiro ZS, Santos JAD, Carneiro JA. Mulheres vivendo com HIV/AIDS: avaliação da qualidade de vida. Rev Saúde Pesquisa [Internet], Maringá, 2014; 7(3):503-13. Available from: http://periodicos.unicesumar.edu.br/index.php/ saudpesq/article/viewFile/3667/2493.

15. Reis RK, Santos CB, Dantas RAS, Gir E. Qualidade de vida, aspectos sociodemográficos e de sexualidade de pessoas vivendo com HIVIAIDS. Texto Cont Enfe [Internet] Santa Catarina, 2011 Jul/Sep; 20(3):565-75. Available from: http://www.scielo.br/pdf/ tce/v20n3/19.pdf.

16. Silva, J, Saldanha, AAW, Azevedo, RLW. Variáveis de impacto na qualidade de vida de pessoas acima de 50 anos HIV+. Psic: reflexão e crítica [Internet] Porto Alegre, 2010 Jan/ Apr; 23(1), 56-63. Available from: http://www.scielo.br/pdf/ prc/v23n1/a08v23n1.pdf. https://dx.doi.org/10.1590/S010279722010000100008

\section{Supporting Agency}

Fundação de Amparo à Pesquisa e Desenvolvimento Científico do Maranhão FAPEMA

Publish in International Archives of Medicine

International Archives of Medicine is an open access journal publishing articles encompassing all aspects of medical science and clinical practice. IAM is considered a megajournal with independent sections on all areas of medicine. IAM is a really international journal with authors and board members from all around the world. The journal is widely indexed and classified Q1 in category Medicine. 